\title{
Förutsättningar för multimodalt meningsskapande i svenskämnets kursplaner på grundlärarutbildningen
}

\author{
Anna-Lena Godhe \& Ann-Mari Edström \\ Malmö universitet, Sverige
}

\begin{abstract}
Med utgångspunkt i en analys av kursplaner för svenskämnet inom grundlärarprogrammet vid fyra svenska lärosäten syftar denna artikel till att belysa skillnader i förhållningssätt till multimodalt meningsskapande samt hur dessa ramar in studenternas möjligheter till multimodalt meningsskapande. Analysen visar på tre huvuddrag i förhållningssättet till multimodalitet: som digitalitet, som stöd för annat lärande och som kunskapande i sin egen rätt. Spänningar mellan dessa tre förhållningssätt utforskas vidare och visar att processen fokuseras då multimodalitet ses som kunskapande i sin egen rätt medan representationen, i form av en produkt, blir det som hamnar i fokus utifrån de andra förhållningssätten. Ett holistiskt synsätt på kvalitativa aspekter av multimodalitet möjliggörs när meningsskapande processen och relationella aspekter fokuseras.
\end{abstract}

Nyckelord: multimodalitet, fenomenografi, performativitet, relationell, kursplaner

\begin{abstract}
Prerequisites for multimodal meaning making in the syllabi for the subject of Swedish at the primary school teacher education programme

Based on an analysis of course syllabi from four Swedish universities, this article aims to illuminate how conceptions of multimodality in these course syllabi frame opportunities for teacher students to interpret and engage in multimodal meaning making. The analysis revealed three conceptualizations of multimodality: as digital, as supporting other learning processes and as knowledge in its own right. Tensions between these conceptualizations were further explored, disclosing that when multimodality was regarded as knowledge in its own right the process of meaning making were in focus. In contrast, the other conceptualizations revealed a focus on representation in the form of a product. A focus on the process of meaning making and relational aspects, rather than representations of knowledge in a product, enable a holistic view on qualitative aspects of multimodality.
\end{abstract}

Keywords: multimodality, phenomenography, performativity, relational, syllabus

\section{INTRODUKTION}

Denna artikel rapporterar resultatet från en studie, vars syfte är att belysa skillnader i förhållningssätt till multimodalt meningsskapande med utgångspunkt i hur dessa skrivs fram i kursplaner för svenskämnet inom grundlärarprogrammet. Svenskämnet har traditionellt sett fokuserat på läsande och skrivande av verbalspråkliga texter. När det gäller andra sätt att uttrycka sig på, t.ex. bild och ljud, saknar svensklärare som regel specifika kunskaper (Tønnessen, 20II). Samtidigt möjliggör och inbjuder dagens digitala kommunikationskanaler till multimodalt

*Författarkontakt: anna-lena.godhe@mau.se

Artiklar och reflektioner är kollegialt granskade. Övriga bidragstyper granskas av redaktionen. Se https://hogreutbildning.se ISSN 2000-7558

(C)2021 Anna-Lena Godhe \& Ann-Mari Edström. This is an Open Access article distributed under the terms of the Creative Commons Attribution 4.0 International License (https://creativecommons.org/licenses/BY/4.0/), allowing third parties to share their work (copy, distribute, transmit) and to adapt it, under the condition that the authors are given credit, that the work is not used for commercial purposes, and that in the event of reuse or distribution, the terms of this license are made clear.

Citation: Godhe, A.-L. \& Edström, A.-M. (2021). «Förutsättningar för multimodalt meningsskapande i svenskämnets kursplaner på grundlärarutbildningen», Högre utbildning, 11(3), 88-106. https://doi.org/10.23865/hu.v11.2995 
meningsskapande där verbalspråk, bild och ljud samspelar. Tidigare studier har synliggjort lärares svårigheter avseende hur multimodalitet kan integreras i undervisningen och hur kvaliteter i multimodalt meningsskapande kan bedömas (Godhe, 20I4; Silseth \& Gilje, 20I7; Aagard \& Silseth, 20I7). Att uttrycka kvaliteter när andra uttryckssätt än de verbalspråkliga används blir ofta problematiskt för både elever och lärare (se t.ex. Borgfeldt, 20I7; Cederlund \& Sofkova Hashemi, 20I8; Godhe, 20I4). För att införliva förändrade kommunikationsmönster i undervisningen har betydande ändringar gjorts i läroplaner för grund- och gymnasieskolan, t.ex. då det gäller digital kompetens, men liknande förändringar har till stor del uteblivit i styrdokumenten för högre utbildning. Mot den bakgrunden ser vi ett behov av att problematisera förutsättningarna för multimodalt meningsskapande i högre utbildning och specifikt för blivande svensklärare.

Lärarprogrammen omnämns ibland som en utbildning men består i själva verket av flera program med olika inriktningar. Dessutom är programmen utformade på olika sätt och omfattar olika kurser vid olika lärosäten. Vi har valt att avgränsa oss till kursplaner i svenskämnet på grundlärarutbildningen med inriktning mot förskoleklass-år 3 (F-3) och år 4-6 vid fyra svenska lärosäten. Anledningen till att kursplaner för grundlärarutbildningen med inriktning mot F-3 och år 4-6 valts ut är dels att dessa år lägger grunden för elevernas meningsskapande, dels att det i läroplanen tydligt skrivs fram att elever under dessa år ska skapa texter där både text, bild och ljud samspelar. I grundlärarutbildningen med dessa inriktningar läser alla studenter 30 hp i svenskämnet men var i utbildningen kurserna ligger varierar. Att kurser i just svenskämnet valts motiveras av att tidigare studier visar på att multimodalt meningsskapande blivit en del av språkundervisningen och att detta innebär en markant förändring i ämneskulturen (Elf et al., 20I8). I studien av Elf et al. (20I8) analyseras hur multimodalitet skrivs fram i läroplaner för grund- och gymnasieskolan i Norden. Resultatet visar att det har skett en förskjutning i läroplanerna mot att elever nu förväntas producera multimodala texter medan fokus tidigare varit på reception, det vill säga att kunna förstå och tolka multimodalitet. Detta skifte från konsument till producent i styrdokumenten ställer ökade krav på medvetenhet kring kvalitativa aspekter av multimodala produktioner hos lärare. I en analys av grundskolans läroplaner från Lgr 69 till Lgr II konstaterar Dahlbäck och Lyngfeldt (2017) att verbalspråket är normen i svenskämnet. De påpekar att det paradigmskifte som bl.a. Kress (20I3) skrivit om innebär en multimodal språksyn där lärande både i och genom olika uttrycksformer förespråkas, men i gällande läroplan, Lgr II ses t.ex. estetiska uttrycksformer fortsatt som ett tillägg till skriftspråket. Inom det estetiska området finns forskning som avser aspekter av multimodalitet, men få studier avser kvaliteter av multimodalt meningsskapande i lärandesituationer. Studier av multimodalitet och lärande inom det estetiska området i högre utbildning lyser i princip med sin frånvaro (Kang et al., 20I7).

Vår studie avser att synliggöra vilka uppfattningar av multimodalitet som formuleras i kursplanerna inom svenskämnet. Formuleringarna visar på det utrymme som lärarstudenterna ges att förstå, tolka och producera multimodala texter under sin utbildning. Eftersom studier med fokus på kursplaner inom högre utbildning är få i en svensk kontext bidrar denna artikel med forskning om hur formuleringar i kursplaner dels verbaliserar vissa uppfattningar om begrepp, dels hur dessa uppfattningar påverkar förutsättningar för innehållet i kurserna. I vår studie undersöks formuleringar av innehåll och mål i kursplanerna, som en del av undervisningens socio-materiella assemblage. Begreppet assemblage är ursprungligen den engelska översättningen av Deleuzes \& Guattaris begrepp agencement (Law, 2004). Ett förslag på svensk översättning är "relationella sammanhang" (Jonasson, 2020, s. 69) vilken förmedlar något av det 
ursprungliga begreppets agens. Ett socio-materiellt assemblage kan då förstås som ett specifikt relationellt sammanhang av sociala och materiella aktörer. Tillsammans med kursguider och kursutvärderingar är kursplaner en del av de juridiska dokument som ramar in innehåll och mål i kurser (Aldrin, 2013) och de får därför agens genom att de reglerar vad som ska tas upp i kurserna. Vi intresserar oss här för kursplaners agens utan att för den skull se dem som direkt föreskrivande eller kontrollerande av all agens som utövas i kurserna. För att kunna studera den agens som kursplaner ges i praktiken av lärare och studenter och vilken agens som andra aktörer (så som rummets fysiska utformning, undervisningsmaterial osv.) ges i undervisningens socio-materiella assemblage, krävs vidare studier av multimodalitet $i$ undervisningspraktiker på lärarprogrammen.

Studien utgår från följande frågor:

- Vilka uppfattningar av multimodalitet kan urskiljas i kursplaner för de utvalda programmen?

- Hur ramar dessa uppfattningar in studenternas förutsättningar för multimodalt meningsskapande?

\section{Multimodalitet och meningsskapande}

Multimodalitet används ofta mer eller mindre synonymt med multimedia och det är inte alltid lätt att skilja dessa åt då de delvis går i varandra. Vi väljer dock att göra en åtskillnad och använder multimedia om digitala media samt när själva mediernas egenskaper fokuseras, snarare än uttrycken. Internet skulle då t.ex. ses som multimedia medan en tryckt dagstidning inte är det. Multimodalitet handlar istället om att ett flertal uttryckssätt ses som meningsbärande. Både internet och en dagstidning är multimodala eftersom båda innehåller så väl text, bild, och layout och alla modaliteter är meningsbärande.

Multimodalitet är centralt i socialsemiotisk teori där tecken och symbolers betydelse studeras. Meningsskapande ses här som ett sätt att tala om lärande (Kress, 20IO). Meningsskapande med det talade och skrivna ordet har en stark ställning när det gäller att uttrycka kunskap, men alla uttryckssätt anses vara meningsbärande inom den socialsemiotiska teorin. På så sätt är socialsemiotiken icke-hierarkisk och ifrågasätter det talade och skrivna ordets särställning, t.ex. inom utbildningsväsendet. Dessutom hävdar t.ex. Kress (2010) att bilder i dagens mediala värld blivit alltmer betydelsefulla och att maktförhållandet mellan olika uttryckssätt på så vis rubbats.

Multimodalitet används även för att beskriva interaktion inom t.ex. konversationsanalys. Fokus ligger då på att vi i kommunikation använder olika resurser så som gester och blickar och att dessa samverkar med tal för att skapa specifika betydelser. Analyserna utgår ofta från videomaterial och beskriver i detalj hur flera modaliteter interagerar. Goodwin (2000) har t.ex. visat hur arkeologer har lärt sig urskilja aspekter av jordavlagringar i sitt yrke och hur de i interaktion lär noviser vad det innebär att se som en arkeolog.

Digitaliseringen av samhälle och utbildningsväsende innebär att multimodalt meningsskapande idag är en del av vår vardag. Även om man kan hävda att allt meningsskapande är multimodalt innebär dagens mediala värld att gemene man frekvent får information och uttrycker sig genom att kombinera flera uttryckssätt och att detta sätt att kommunicera blivit en del av mångas vardag. I sms och mail t.ex. ingår ofta symboler så som emojis, och information delas $\mathrm{i}$ filmklipp som innehåller både bild, musik, tal och skrift. Studier av multimodalitet ur ett socialsemiotiskt perspektiv tenderar att fokusera på ett uttryckssätt i taget, men både Bezemer och Kress (2016) och Christensen (2017) påpekar vikten av att studera hur flera olika modaliteter 
samspelar för att skapa mening. Andra studier undersöker studenters förståelse och skapande av multimodala texter. Cederlund och Sofkova Hashemi (20I8) har i en svensk kontext undersökt hur lärare i grundskolan kan utveckla sin förståelse för kvalitet i multimodala texter. De konstaterar att svenskämnets kärna (skriftspråkliga regler, organisering av text och kommunicerande av innehåll) utmanas av multimodala och digitala texter. Genom att kvalitativa aspekter av multimodala texter uppmärksammas ökar lärarnas förståelse för dessa. Samtidigt menar de att lärarna måste förhålla sig till formuleringar i styrdokument, vilka främst relaterar till verbalspråkliga kvaliteter. Molin och Godhe (2020) har studerat hur elevers kritiska analys av multimodala texter kan stöttas i undervisningen. Genom att dekonstruera multimodala texter och fokusera på en modalitet i taget, utvecklade eleverna sin kritiska analys av olika perspektiv i texterna. En slutsats är dock att eleverna behöver ytterligare stöttning $\mathrm{i}$ att förstå, tolka och analysera hur olika modaliteter tillsammans bidrar till meningsskapande. Elf et al. (20I8) beskriver förändringar i nordiska läroplaner avseende multimodalitet. De pekar på att fokus håller på att flyttas från elevers receptiva förmåga, dvs. förmåga att analysera multimodala representationer, mot det Elf et al. benämner som performativitet dvs. elevers förmåga att själva producera multimodala representationer. Performativiteten relateras här till skapandet av en produkt som kan bedömas och sätts i motsats till att förstå och analysera representationer skapade av andra.

\section{TEORETISK KONTEXT}

Vi har valt att använda en kombination av fenomenografi och socio-materiell teori i analysen av kursplanerna. Såväl en fenomenografisk ansats som socio-materialistisk teori bygger på en relationell syn på kunskap som icke-dualistisk och transformativ, det vill säga som kvalitativ förändring snarare än förmedling (se t.ex. Barad, 2007; Marton \& Booth, 1997). Det är dock enligt vår erfarenhet ganska sällan som socio-materiell teori sätts i en kontext av andra relationella teoribildningar. Genomförandet av denna studie kan ur den aspekten ses som ett teoretiskt prövande. Fenomen ses som grundläggande epistemologiska entiteter inom såväl fenomenografin som hos Barad (t.ex. Barad, 2007; Svensson, 1997) även om det finns skillnader mellan synsätten. Bl.a. fokuserar fenomenografin relationen mellan människa och fenomen medan Barads förståelse av fenomen innefattar alla former av relationer, såväl mänskliga som materiella.

Fenomenet multimodalitet förstås i denna studie som ett komplex av relationer som omfattar såväl materiella som mänskliga relationer, så i den meningen antar studien en socio-materiell syn på agens (jfr t.ex. Barad, 2007; Latour, 20I5; Law, 2004). Som valet av fenomenografi indikerar, ses samtidigt den mänskliga erfarenheten som en värdefull tillgång i forskningssammanhang: "all actors cannot be treated as completely symmetrical for research purposes because of the particular access that we have to accounts of experience from human actors" (Jones, 2018, s. 5I). Även fenomenografins avgränsade studieobjekt, uppfattningar (även kallat erfarande), är intimt relaterade till såväl mänsklig aktivitet som människans materiella och sociala sammanhang (Svensson, 1997). Uppfattningars relationella karaktär beskriver Svensson så här:

what is to be described as a conception is not everything done or said during a certain period of time or in a certain situation, but a relation between an individual and a part of the world. The conception has to be described on the basis of a manifestation of such a relation. (I997, s. 169)

En fenomenografisk ansats används inledningsvis för att urskilja uppfattningar av multimodalitet så som de kommer till uttryck i kursplanernas skrivningar. Socio-materialistisk teori används 
sen för att adressera diskursiva förutsättningar för multimodalt meningsskapande, utifrån de uppfattningar som urskilts.

För att utforska de spänningar som framträder i kursplanerna utgår vi från Karen Barads samt Judith Butlers tidiga resonemang kring begreppet diskursiva praktiker. Butler (bl.a. 1993) och Barad (bl.a. 2007) skriver om diskursiva praktiker utifrån delvis olika utgångspunkter. Medan Butler intresserar sig för diskursiva praktikers funktion, uppmärksammar Barad hur diskurser materialiseras. Butler fokuserar på verbalspråket och hur det konstruerar individer. Språket reflekterar inte en verklighet utan konstruerar den. Även om Butler inte bortser från materialitet, kritiserar Barad henne för att fokusera på hur "discourse comes to matter" men inte hur "matter comes to matter" (Barad, 1998, s. 9I). Om en beskrivning av materialisering främst uppmärksammar diskursiva begränsningar menar Barad att den snarare förstärker förställningen om det materiella som något passivt. Ett konkret exempel på när verbalspråket tas som utgångspunkt på bekostnad av det materiella skulle kunna vara en bedömningssituation $\mathrm{i}$ skolan där multimodala aspekter av texter osynliggörs genom att ses som något som har med formen snarare än innehållet att göra.

Vidare används Barads begrepp performativitet för att analysera de diskursiva förutsättningar för multimodalt meningsskapande som urskilts i kursplanerna. Barads förståelse av begreppet kan, något förenklat, definieras såhär: "A performative understanding [...] takes account of the fact that knowing does not come from standing at a distance and representing but rather from a direct material engagement with the world." (2007, s. 49, kursiv i original). Bortsett från Barads betoning på det materiella, så är förståelsen av performativitet som ett "engagerande", i motsats till ett representerande, central i en relationell, transformativ syn på kunskap. Även andra (t.ex. Biesta, 2004) har uttryckt performativitet i relation till meningsskapande och kommunikation. För såväl Biesta (2004) som Barad (2007) innebär performativitet ett aktivt engagerande karaktäriserat av en ömsesidighet och ett intimt beroende vilket även kommer till uttryck i fenomenografins interna relation mellan människa och erfaret fenomen (t.ex. Marton \& Booth, 1997).

Performativitet kan, som visat ovan, definieras på flera olika sätt. Ball (t.ex. 2000) fokuserar på representationer som kan bedömas, medan Biesta (2004) och Barad (2007) knyter an till ett görande och engagerande. Denna skillnad skulle kunna definieras som performativitet i relation till produkt eller process. I en representativ syn på performativitet blir det centrala en produkt i form av en multimodal representation som kan bedömas och där färdigheten i att göra denna kan tränas. En relationell kunskapssyn definierar istället performativitet som ett görande eller "engagerande" och sätter det inte i relation till att prestera eller åstadkomma något specifikt. Performativitet framstår i den meningen som motsatsen till representation (Barad, 2007) då det främst är genom socio-materiellt engagerande som kunskap uppstår, inte genom verbalisering och representationer.

\section{UPPLÄGG OCH GENOMFÖRANDE}

Studiens material utgörs av textdokument i form av kursplaner. Fenomenografi förknippas huvudsakligen med intervjuer men ansatsen har egentligen ingen sådan metodisk begränsning. Istället betonas vikten av att anpassa metod efter forskningsobjekt: "[A phenomenographic research approach] means an emphasis on approaching the research objects in the sense of creating methods adapted to the objects" (Svensson, 1997, s. I62). Användningen av intervjuer inom fenomenografin har heller inte att göra med att uppfattningar enbart skulle kunna uttryckas verbalt; uppfattningar kan uttryckas på många sätt (Svensson, 1997). Några exempel på materialvariation i fenomenografiska studier är textdokument (Bruce, 1994; MacMillan, 20I4), text- och 
bildportfolios (Edström \& Wangen, 2020), observerade och filmade lektioner (Maybee et al., 20I7), videodagböcker (Körkkö et al., 2019), cultural probes (Speed, 2008) och gester (Herbert $\&$ Pierce, 2013).

Studien omfattar kursplaner från fyra universitet - Göteborg, Karlstad, Malmö, Örebro vilka valdes ut för att få en variation av såväl mindre som större lärosäten. Sammanlagt Is kursplaner i svenska för grundlärarutbildningen med inriktning mot F-3 och 4-6 hämtades från universitetens hemsidor under oktober 20I9. Urvalet täcker de $30 \mathrm{hp} \mathrm{i} \mathrm{svenska} \mathrm{som} \mathrm{studenterna}$ läser. I vissa fall ingår VFU-kurser som delkurser i kursplanerna, men dessa delkurser har exkluderats eftersom studien avgränsas till högskoleförlagda kurser. Kursplaner är levande dokument där innehållet fortlöpande revideras och kurskoder byts. Därför ska materialet för studien ses som ett nedslag vid tidpunkten ifråga och inte som en bild av hur det ser ut idag. Av samma anledning skulle det vara missvisande att här referera till kursplanerna med kod och länkar, då den typen av information snabbt blir inaktuell.

Vi valde att fokusera på kursplanernas lärandemåls- och innehållsskrivningar i analysen. Kursplaner vid en del lärosäten inkluderar syftesskrivningar, men inte alla, därför valdes syften bort. Inledningsvis var även avsikten att inkludera formen för bedömning av lärandemålen, men alltför stora olikheter vad gäller detaljnivån gjorde att de inte gick att jämföra och analysera.

Kursplanerna lästes först med siktet inställt på skrivningar som uttryckligen avsåg multimodalitet, antingen genom konkret användande av ordet multimodal i någon form eller genom framskrivande av samspel mellan olika uttrycksformer. Då det gav ett magert resultat utökades läsningen till att omfatta även det vi såg som näraliggande skrivningar. Dessa definierades, medvetet brett, som skrivningar som avsåg kommunikations- och uttrycksformer utöver den inom svenskämnet verbalspråkliga normen, i linje med förändringar i grundskolans läroplan. Dessa skrivningar kunde löst grupperas som estetiska samt digitala. I denna gruppering användes ordet estet i någon form, alternativt så skrevs det estetiska fram som gestaltande uttrycksformer, drama, visuella gestaltningar och liknande. Valet att ta med digitala skrivningar gjordes eftersom vi redan vid de första genomläsningarna av kursplanerna såg att multimodalt ofta uppfattades som något digitalt. Några exempel på formuleringar i denna gruppering är digitala medier så som film och dataspel samt sammankopplingar av multimodala och digitala medier respektive multimodalt och digitalt berättande.

Initialt analyserades kursplanerna inom respektive lärosäte eftersom skrivningarnas innebörd är avhängig den lokala kontexten. Syftet med studien är dock inte att utvärdera varje enskilt universitet. I linje med ett fenomenografiskt angreppssätt, behandlades därför resultatet senare som en helhet, med fokus på den sammanlagda variationen av de urskilda uppfattningar. Vi har valt att inkludera båda dessa analysfaser i resultatpresentationen så att läsaren kan följa analysprocessen. Under rubriken "Multimodalitet i kursplanerna" ges exempel på detaljnivå som visar vilka skrivningar som legat till grund för de uppfattningar som urskiljts. Därefter summeras de totalt elva uppfattningar som urskiljts i närläsningen av kursplanerna under rubriken "Uppfattningar av multimodalitet i kursplanerna" och sammanfattas i tre huvudgrupper: multimodalitet som något digitalt, multimodalitet som stöd för annat lärande och multimodalitet som kunskapande $i$ sin egen rätt. De uppfattningar som beskrivs, och grupperingen av dessa, ska inte förstås som exkluderande varandra. Uppfattningar om multimodalitet som stöd för annat lärande kan t.ex. även omfatta synen på multimodalitet som något digitalt. Inte heller ska de förstås som de enda som kan urskiljas i materialet. De uppfattningar som presenteras är de som för oss framstått som mest signifikanta under analysen. Alla former av kategorisering innebär ett visst mått av förenkling. Samtidigt ska resultatet kunna kommuniceras i en förståelig form. Balansgången 


\section{Anna-Lena Godhe \& Ann-Mari Edström}

mellan förenkling och komplexitet har styrts av viljan att så tydligt som möjligt beskriva de mest framträdande uppfattningarna.

I presentationen av resultatet används olika begrepp för att beskriva det vi ser i materialet, varav vissa kan behöva en introduktion. Ett sådant begrepp är om-kunskap. Med det avses en mer distanserad kunskap och förståelse om något, snarare än praktisk erfarenhet. Att läsa om multimodala uttrycksformer men inte själv prova att arbeta med dessa, är ett exempel på om-kunskap. För att beskriva den kunskap som utvecklas genom att själv arbeta praktiskt med multimodala uttrycksformer, används olika former av ordet praktik. I skrivningar som uttrycker en syn på multimodalitet som medel för annat lärande, skrivs inte multimodalitet fram som ett självständigt kunskapsområde. Istället används multimodalitet för att utveckla andra förmågor, t.ex. barns läs- och skrivutveckling eller identitetsskapande. Denna uppfattning är välbekant för verksamma inom estetiska ämnen, och ses här även i relation till multimodalitet. Som kontrast till en syn på multimodalitet som medel för annat lärande förekommer skrivningar som uttrycker begreppet multimodalitet som egen kunskapsform. Dessa skrivningar ger uttryck för en mer holistisk uppfattning av multimodalitet, vilken omfattar såväl praktiskt arbete som ett mer distanserat förhållningssätt till multimodalitet. Multimodalitet framträder som en egen kunskapsform med specifika förutsättningar och ett eget värde. I kursplanerna förekommer även skrivningar där denna holistiska förståelse av multimodalitet uttrycks, men där utrymme för praktiska erfarenheter av multimodalitet inte ges utrymme. Vi benämner detta som multimodalitet som idé.

\section{MULTIMODALITET I KURSPLANERNA}

Här redovisas resultatet av närläsningen av de fyra lärosätenas kursplaner. Exempel på skrivningar som uttrycker uppfattningar av multimodala kvaliteter i lärande och undervisning presenteras som multimodala, estetiska och digitala i linje med den ovan beskrivna grupperingen. I varje avsnitt sammanfattas och förklaras dessutom de uppfattningar som urskiljts vid varje lärosäte. Totalt framträder följande elva uppfattningar av multimodalitet; som kunskapsform, praktik, idé, berättande, text, förberedelse, media, litteracitet, konsumtionsvara, stöd och jämförelseobjekt. I de fall lärandemåls- och innehållsskrivningar som citeras är en del av en längre skrivning, har enbart den del av relevans för studien tagits med. De citerade målen benämns med en siffra och första bokstaven i lärosätets ortsnamn, t.ex. G2 och Öı. Detta görs för att enkelt kunna hänvisa till citaten genomgående i texten.

\section{Göteborgs universitet}

I Göteborgs material återfinns multimodala skrivningar i tre av de fyra kursplaner som hämtats ( 2 kursplaner för F-3 och 2 för 4-6, samtliga Is hp). Skrivningar saknas i en 4-6 kurs. Exempel på lärandemålsskrivningar:

Gi. planera för och förklara hur estetik, multimodala arbetsformer och arbetssätt kan användas i undervisningen för att stödja elevers språk-, läs- och skrivutveckling. $(\mathrm{F}-3 \text {, färdighet och förmåga })^{\mathrm{I}}$

\footnotetext{
1 Göteborgs universitet är det enda lärosäte i studien som valt att indela målen i kursplanerna enligt högskoleförordningens kategorier kunskap och förståelse, färdighet och förmåga samt värderingsförmåga och förhållningssätt.
} 
G2. visa fördjupad förståelse för vad multimodala uttrycksformer innebär samt hur och varför de kan stötta elevers kommunikation och identitetsskapande. (F-3, kunskap och förståelse)

G3. reflektera över skönlitteraturens och estetikens betydelse för individens identitet och omvärldsuppfattning samt läsningens betydelse för fortsatt läsutveckling (4-6, kunskap och förståelse)

G4. visa förmåga att använda digitala verktyg (F-3, färdighet och förmåga)

Multimodala skrivningarna används explicit i GI och G2, båda inom inriktningen F-3. Verben som används i de två målen indikerar om-kunskap eftersom studenten inte själv uttryckligen ska praktisera multimodala uttrycksformer. Det multimodala skrivs i innehållsbeskrivningar explicit fram som multimodala arbetsformer, arbetssätt, uttrycksformer, synsätt och medier. I anslutning till dessa skrivningar, framkommer det praktiska multimodala görandet, men det praktiska görandet avser vad studentens blivande elever ska göra, inte studenten själv. I relation till studentens lärande är det sammantaget om-kunskaper som skrivs fram. Även om Gi enligt högskoleförordningens kategorisering avser färdighet och förmåga, uttrycker det om-kunskaper när det gäller multimodalitet eftersom det är didaktiska färdigheter i att planera som avses och inte multimodala färdigheter. Skrivningarna uttrycker även primärt hur multimodalitet kan användas för att stödja annat lärande så som språk- läs- och skrivutveckling, kommunikation och identitetsskapande (GI \& G2).

Begreppet estetik används tillsammans med multimodalitet i Gi samt G3. Estetik är ett mångfasetterat teoretiskt-filosofiskt begrepp som för våra tankar till det akademiska ämnet estetik. I innehållsbeskrivningarna nämns ordet estetik (kursplan för F-3) samt estetiska uttryck (kursplan för 4-6) men estetikbegreppet definieras inte någonstans. Oavsett definition så indikerar skrivningarna i första hand om-kunskaper. Vidare handlar det om hur estetik kan stödja något annat så som identitet, omvärldsuppfattning $\left(G_{3}\right)$ och språk- läs- och skrivutveckling (innehållsbeskrivning).

Digitala verktyg omnämns i flera lärandemål, t.ex. i G4. Medier skrivs fram tillsammans med digitalitet, bl.a. förekommer flera varianter av skrivningen "medier och digitala verktyg". Alla mål som nämner digitala verktyg avser om-kunskap, utom just detta mål. I målen som uttrycker om-kunskap används verben visa medvetenhet, kännedom eller insikt om samt analysera i relation till digitala verktyg och medier. Detta indikerar en metanivå av om-kunskapen som vi förknippar med digital-medial litteracitet.

Sammanfattningsvis urskiljs fem uppfattningar av multimodalitet:

- som egen kunskapsform

- som idé

- som del av en digital-medial litteracitet

- som stöd för annat lärande

- som förberedelse

Uppfattningen om multimodalitet som egen kunskapsform grundar sig i att multimodala arbetsformer, uttrycksformer och synsätt explicit skrivs fram. Men även om multimodalitet skrivs fram som en egen kunskapsform i relation till studentens framtida elever, så avser kursplanerna om-kunskap ur studentens perspektiv. Studentens lärande i form av att erfara multimodalt görande och utveckla praktiska kunskaper ges inte explicit utrymme i kursplanerna. 
Därmed synliggörs här en uppfattning om multimodalitet som idé, snarare än som praktik. Uppfattningen om multimodalitet som del av en digital-medial litteracitet grundar sig i att digitala verktyg, medier och arbetsformer frekvent omnämns i kursplanerna, och att detta görs genom verb på metareflektionsnivå, så som visa medvetenhet om samt analysera. Uppfattningen om multimodalitet som stöd för annat lärande grundar sig i att multimodalitet explicit skrivs fram som stöd för språk-, läs- och skrivutveckling, kommunikation samt identitetsskapande. Att multimodala skrivningar helt saknas i en 4-6-kurs, antyder att multimodalitet ses som mer relevant för yngre barn och som förberedelse för ett verbalspråkligt meningsskapande.

\section{Karlstads universitet}

I Karlstads material återfinns multimodala skrivningar i samtliga tre kursplaner som hämtats (2 kursplaner för F-3, Is hp vardera, samt I kursplan för 4-6, 30 hp). Exempel på lärandemålsskrivningar:

KI. tillämpa kunskaper om multimodalt berättande (F-3)

K2. beskriva hur man med grundläggande grammatiska kunskaper formar en kreativ grammatik-undervisning med inslag av estetiska lärprocesser (F-3, 4-6)

$\mathrm{K}_{3}$. redogöra för hur dokumentation och bedömning av elevers lärande kan användas $\mathrm{i}$ undervisning och pedagogisk verksamhet där även estetiska lärprocesser integreras (F-3)

Multimodalitet skrivs explicit fram som multimodalt berättande i KI. Målformuleringen uttrycker om-kunskaper men omfattar också färdigheter genom att kunskaperna ska tillämpas. Det multimodala kopplas till färdigheter i digitalt berättande som skrivs fram som en del av studentens skrivprocess i innehållsbeskrivningen. Detta indikerar en uppfattning om det multimodala som något primärt digitalt.

Estetiska skrivningar i kursplanerna avser explicit estetiska lärprocesser. Även i relation till det estetiska avser lärandemålen om-kunskap genom verb som beskriva och redogöra för (t.ex. K2). I innehållsbeskrivningar nämns estetiska lärprocesser i allmänna ordalag. De estetiska lärprocesserna ska uppmärksammas respektive behandlas men kursplanerna uttrycker inte att studenten ska visa på färdigheter i att praktiskt arbeta estetiskt. Estetiska lärprocesser skrivs även fram som stöd för grammatikundervisning i K2. I syftningen i $\mathrm{K}_{3}$, som även avser estetiska lärprocesser, är det något oklart huruvida det är bedömningspraktiken eller den pedagogiska verksamheten i allmänhet som avses. Av innehållsbeskrivningarna framgår dock att kursen behandlar hur estetiska lärprocesser kan fördjupa bedömning av elevers lärande, därför tolkas lärandemålet i linje med detta. Estetiska lärprocesser ses således som något som stöttar ett annat lärande.

Explicita digitala skrivningar förekommer enbart i innehållsbeskrivningarna. Multimodalt berättande, som nämns i KI, ges en digital kontext genom att den tillhörande innehållsskrivningen nämner initierandet av "en skrivprocess som leder fram till ett digitalt berättande". Vidare framkommer av innehållsbeskrivningarna att "Skönlitteratur diskuteras i jämförelse med andra berättande medier, så som film, television och dataspel" (kursplan för F-3). Skönlitterärt berättande jämförs alltså med digitala medier. Berättande i både skönlitteratur och digitala medier är vanligt förekommande exempel på multimodala berättarformer, men i skrivningarna görs kopplingar mellan multimodalitet som specifikt digitalt medan det skönlitterära inte explicit kopplas till varken digitala skrivningar eller multimodalitet. 
Sammanfattningsvis urskiljs sex uppfattningar av multimodalitet:

- som digitalt berättande

- som praktik

- som idé

- som jämförelseobjekt

- som stöd för annat lärande

- som förberedelse

Uppfattningen av multimodalitet som digitalt berättande grundar sig i den ovan beskrivna tolkning av målformuleringar i relation till tillhörande innehållsbeskrivningar, där en implicit uppfattning om multimodalitet som något digitalt framträder. Uppfattningen av multimodalitet som praktik ser vi i tillämpandet av multimodala berättarkunskaper i KI, likaså i det digitala berättandet som framgår av innehållsbeskrivningen. Något utrymme för studenten att utveckla praktiska multimodala färdigheter och kunskaper går dock inte att utläsa i kursplanernas formuleringar. Andra kurser kan självfallet ha förberett för detta, men sett till denna studies svenskämneskontext så verkar detta utrymme för studenten saknas. Vad det innebär att utveckla en förståelse för multimodalitet är heller inte tydligt i kursplanernas formuleringar. Förutom att tillämpa multimodalt berättande handlar målen om hur estetiska lärprocesser kan integreras i undervisning, vilket även det kräver redan utvecklade kunskaper och färdigheter. Därför ser vi spår av en uppfattning av multimodalitet som idé, men inte som kunskapsform. Uppfattningen av multimodalitet som stöd för annat lärande grundar sig i explicita skrivningar om hur estetiska lärprocesser kan användas för att stärka ett överordnat lärande, så som grammatikundervisning, bedömning och dokumentation av elevers lärande. Ser man till förekomsten av multimodala skrivningar i kursplanerna så urskiljs även uppfattningen om multimodalitet som förberedelse för det verbalspråkliga genom att skrivningarna företrädesvis återfinns på F-3-nivå. Till sist används multimodalt-digitalt berättande i jämförelser med skönlitterärt berättande, vilket ligger till grund för uppfattningen om multimodalitet som jämförelseobjekt.

\section{Malmö universitet}

I Malmös material återfinns multimodala skrivningar i samtliga fyra kursplaner som hämtats (2 kursplaner för F-3 och 2 kursplaner för 4-6; samtliga I5 hp). Exempel på lärandemålsskrivningar:

Mi. i dialog med andra analysera och diskutera skönlitteratur, digitala och multimodala texter och andra elevnära texter för barn (F-3, 4-6)

M2. genom drama visa hur barns läs- och skrivutveckling och kreativitet kan stimuleras (F-3, 4-6)

M3. kritiskt granska och ta ställning till val av läromedel, litterära och visuella texter $\mathrm{i}$ en språkligt och kulturellt heterogen skola (4-6)

M4. säkert och kritiskt hantera digitala verktyg för textproduktion och lärande (4-6)

Multimodalitet finns explicit framskrivet på tre ställen i Malmö universitets kursplaner, alla tillsammans med digitalitet och text i form av frasen "digitala och multimodala texter". Frasen finns med i två mål exemplifierat av MI (det andra målet är snarlikt). Det tredje omnämnandet finns i innehållsbeskrivningar, även där som en del av en uppräkning av olika textformer. I en innehållsbeskrivning finns utöver detta en formulering om text med digital och multimodal underton: "en vidgad syn på text med nya medier och populärkulturella uttrycksformer" 
(F-3 \& 4-6). Ett vidgat textbegrepp nämns här explicit och märks även mer generellt, om än implicit, i kursplanerna. Samtidigt upprätthålls en viss åtskillnad genom att särskilja skönlitteratur från digitala och multimodala texter $\left(\mathrm{MI}_{\mathrm{I}}\right)$ och litterära från visuella texter $\left(\mathrm{M}_{3}\right)$.Det estetiska finns framskrivet som drama i $\mathrm{M}_{2}$ och som visuella texter i M3. I innehållsbeskrivningarna finns inga explicita estetiska skrivningar. Studenten ska utveckla sina egna praktiska kunskaper i drama (M2) med syftet att stödja annat lärande, i detta fall läs- och skrivutveckling hos elever. Inga innehållsbeskrivningar finns som kan ge målet kontext, därför är vår tolkning att det främst är praktiska färdigheter som avses.

Det digitala har en stark närvaro i Malmös kursplaner. Exempel på explicita skrivningar i mål och innehåll är digital kompetens, digital undervisningspraktik, digitala och multimodala texter, webbtexter och digitala verktyg. Totalt sju mål avser om-kunskaper och ett praktiska färdigheter $\left(\mathrm{M}_{4}\right)$. I om-kunskapsmålen används verb så som redogöra, analysera, diskutera, och reflektera.

Sammanfattningsvis urskiljs tre uppfattningar av multimodalitet:

- som digital text

- som praktik

- som stöd för annat lärande

Uppfattningen om multimodalitet som digital text grundar sig i den frekventa kopplingen av multimodalitet till text, specifikt digital text. En text som inte är digital kan givetvis vara multimodal, men en särskiljning görs mellan litterära, skönlitterära texter och multimodala, digitala texter. Uppfattningen om multimodalitet som praktik grundar sig i målskrivningen som specifikt avser användande av drama $\left(\mathrm{M}_{2}\right)$. Dock saknas skrivningar som tyder på en mer holistisk förståelse av vad multimodala arbetssätt och uttrycksformer innebär. Grundat på detta ses skrivningarna inte uttrycka det som vi benämner som en uppfattning av multimodalitet som kunskapsform eller idé. Uppfattningen av multimodalitet som stöd för annat lärande grundar sig i skrivningarna om barns och elevers läs- och skrivutveckling och kreativitet som ska stimuleras genom drama $\left(\mathrm{M}_{2}\right)$.

\section{Örebro universitet}

I Örebros material återfinns multimodala skrivningar i samtliga fyra kursplaner som hämtats ( 2 kursplaner för F-3 och 2 kursplaner för 4-6; samtliga Is hp). Exempel på lärandemålsskrivningar:

Öı. kunskap om några typiska skillnader mellan en litterär berättelse och en filmadaption av samma verk (F-3, 4-6)

Ö2. kunskap om digitala och analoga resurser och verktyg för läs- och skrivundervisningen i mellanåren $(4-6)$

Ö3. diskutera och värdera mediers och IKT-resursers didaktiska potentialer (F-3, 4-6)

Några explicita former av ordet multimodalitet finns inte i kursplanerna. Estetiska skrivningar kan urskiljas i form av film som benämns både som filmmedie och filmadaption. Dramer och dramatik nämns också, men kontexten gör att vi tolkar det som verbalspråklig text: "Vi studerar och diskuterar olika genrer som bilderböcker i vid bemärkelse, dikter, dramer, [dramatik i liknande skrivning för F-3] sagor, realistiska och fantastiska berättelser, och vi gör vissa jämförelser med filmmediets sätt att gestalta” (innehållsbeskrivning 4-6). Filmmediet verkar här främst användas för att jämföra med andra berättelseformer. Även om de andra berättelseformerna 
som nämns förekommer i film-formatet gör det faktum att de olika genrerna ska jämföras att det sannolikt är berättelser i form av text och eventuellt bild som avses. På så vis åtskiljs filmiskt berättande som något annat och som en jämförelsegrund där det filmiska ges rollen som "det andra”.

Explicit digitala skrivningar och digitala kommunikationsformer finns med i $\mathrm{Ö}_{2}$ och $\mathrm{O}_{3}$ (liknande finns även för F-3). Båda skrivningar avser om-kunskap. I Ö2 skrivs detta explicit som "kunskap om" medan det i Ö 3 handlar om att diskutera och värdera didaktisk potential. Det pekar i sin tur på att det inte är resurserna i sig som diskuteras och värderas utan snarare hur de är medel för något annat. Utöver detta så kan de nämnda skrivningarna om filmmediet och filmadaption förmodas vara digitala. Film har över huvud taget en stark närvaro i Örebros kursplaner, och det är det enda medium som specificeras. Filmmediet används också som jämförelseobjekt i relation till litterärt berättande, vilket framgår av Öı samt den citerade innehållsbeskrivningen ovan.

Sammanfattningsvis urskiljs fyra uppfattningar av multimodalitet:

- som digitala medier

- som konsumtionsvara

- som jämförelseobjekt

- som stöd för annat lärande

Uppfattningen av multimodalitet som digitala medier grundar sig huvudsakligen i den frekventa framskrivningen av film som medium i mål och innehållsbeskrivningar. Om inte annat specificeras, så definieras film som ett digitalt medium idag. Film är också ett medium som gärna används som representant för multimodalitet i olika sammanhang, inte minst inom svenskundervisning (t.ex. Olin-Scheller, 2006). Medier nämns även i anslutning till IKT-resurser (Ö3) vilket vi därför tolkar som att det avser digitala medier. Uppfattningen av multimodalitet som konsumtionsvara grundar sig i jämförelserna mellan filmiskt berättande och andra former av berättande. Att jämföra "en litterär berättelse med en filmadaption av samma verk" (ÖI) handlar om att inta en betraktarposition, att konsumera. Att läsa verbalspråklig text är förvisso också konsumtion, men det kompletteras av studenternas egna textproducerande under kursen. Film verkar vidare enbart användas i jämförelser med andra berättelseformer vilket stöder uppfattningen om multimodalitet som jämförelseobjekt. Framskrivandet av film som jämförelseobjekt i analyser av andra berättargenrer ligger också till grund för uppfattningen av multimodalitet som stöd för annat lärande. Skrivningen "vi gör vissa jämförelser med filmmediet" i relation till den rika flora av litterära berättargenrer som räknas upp, stärker uppfattningen att film (multimodalitet) används som stöd och bakgrund till det verbalspråkliga.

\section{UPPFATTNINGAR AV MULTIMODALITET I KURSPLANERNA}

Sammanfattningsvis omfattar resultatet elva uppfattningar av multimodalitet; som kunskapsform, praktik, idé, berättande, text, förberedelse, media, litteracitet, konsumtionsvara, stöd och jämförelseobjekt. Vi har valt att sammanställa dessa i form av visualiseringar. Varje lärosäte representeras av en färg enligt följande:

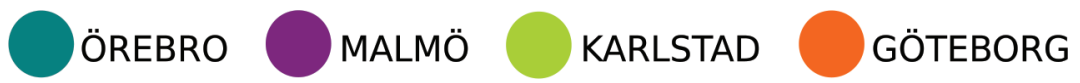

Figur I. Varje lärosäte representeras av en färg 
Genom att visualisera resultatet synliggörs relationer som annars kan gå förlorade i en verbalspråklig kategorisering. Följande visualisering visar utfallsrummet, alltså den variation av uppfattningar av multimodalitet som urskiljts i analysen:

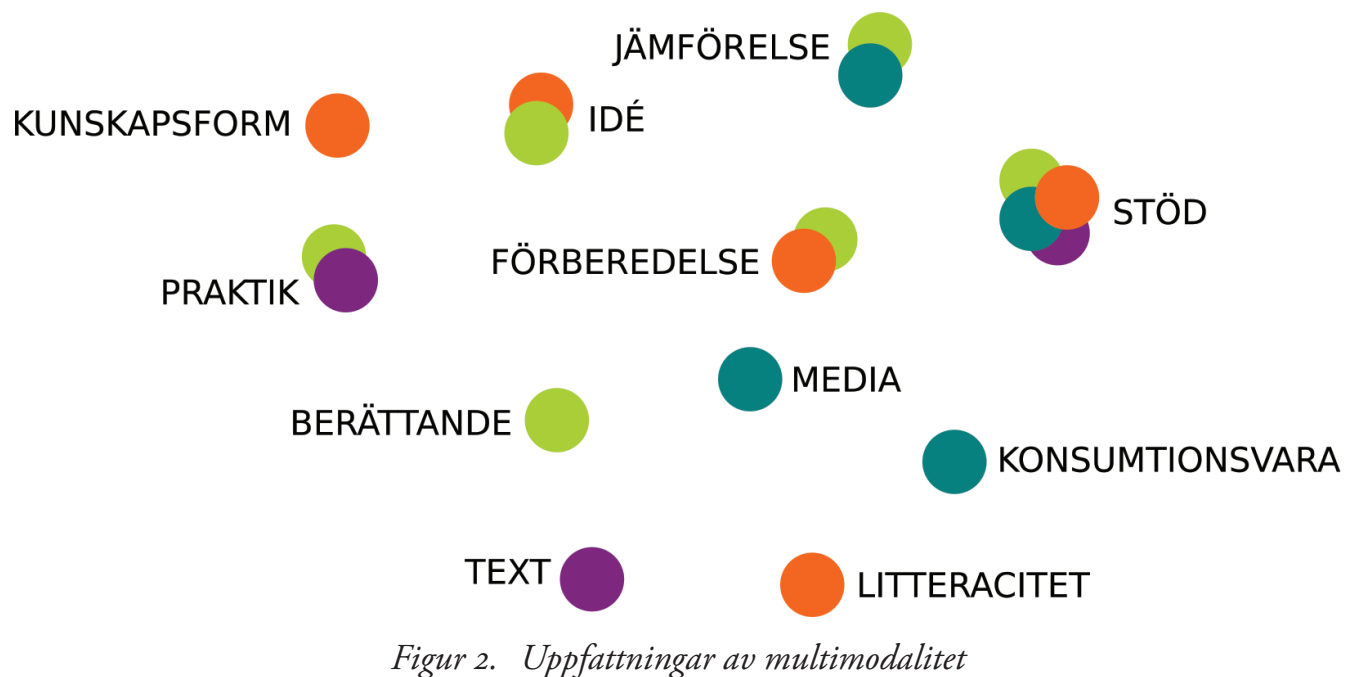

Visualiseringen är ett försök att komma ifrån en sedvanlig hierarkisk kategorisering i tabellform och istället förstå utfallsrummet som en rymd, ett utrymme. Vi vill visa på helheten av och variationen i detta utrymme, utan att rangordna de olika uppfattningarna. Det finns således ingen värdering i de olika prickarnas placering, färgval etc. Här frångår vi den fenomenografiska traditionen av att hierarkiskt kategorisera resultatet till förmån för en mer jämställd eller, om man så vill, platt framställning av helheten. Även om resultatet i fortsättningen diskuteras som en helhet och inte på detaljnivå, gör lärosätenas olika färger att det fortfarande är möjligt att urskilja varje lärosäte; genom att spåra t.ex. alla orangea prickar i visualiseringen ges en bild av de uppfattningar som urskiljts vid Göteborgs universitet. Vidare visar flera olikfärgade prickar vid en uppfattning att den urskiljts vid flera lärosäten. Uppfattningen om multimodalitet som stöd för annat lärande är t.ex. den enda uppfattning som framträtt vid alla fyra lärosäten. Det är dock viktigt att ha i minnet att detta enbart säger något om förekomsten av en uppfattning och inte något om dess kvantitet.

Inom utfallsrummet kan uppfattningarna i sin tur delas in i tre tematiska grupperingar: multimodalitet som något digitalt, multimodalitet som stöd för annat lärande och multimodalitet som kunskapande $i$ sin egen rätt. Som nämnts innan, ska dessa inte förstås som exkluderande varandra. Syftet med grupperingen är att synliggöra tre huvuddrag av relevans för studien, för att sedan diskutera dessa mer ingående.

\section{Multimodalitet som något digitalt}

Den första tematiska grupperingen visar en uppfattning om multimodalitet som något digitalt. Grupperingen, här visualiserad genom ett direkt urklipp ur helhetsbilden, omfattar uppfattningarna av multimodalitet som text, berättande, media, konsumtionsvara och litteracitet. Den digitala kopplingen baserar sig på att alla dessa uppfattningar tydligt kopplar samman multimodalitet med digitalitet i kursplaneskrivningarna. 


\section{BERÄTTANDE}

MEDIA

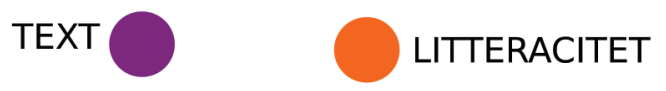

KONSUMTIONSVARA

Figur 3. Multimodalitet som något digitalt

Som konstellationen av prickar visar är det digitala närvarande vid alla lärosäten. Digitala texter, digitalt berättande och digitala medier skrivs alla fram med kopplingar till multimodalitet. Det digitala tenderar att överordnas det multimodala i skrivningarna, och studenten möter företrädesvis digitala-multimodala media som åskådare och konsument snarare än producent. Multimodalitet är alltså nära förknippat med det digitala i kursplanerna (jfr Elf et al., 20I8). Det finns också ett fokus på teknik och media i skrivningarna, vilket vi ser som ett sätt att dela upp multimodalitet (och digitalitet) till delar som lättare kan hanteras, tränas, mätas. Detta förtingligande för tanken till de klassiska fenomenografiska begreppen atomistisk och holistisk (Svensson, 1976), alltså ett fokuserande på isolerade delar av ett fenomen istället för dess mer holistiska kvaliteter. Sefton-Green et al. (2009) drar utifrån studier av norsk undervisning slutsatsen att uppdelningen på dels media och dels teknik har lett till att undervisning om media i huvudsak görs i samhällsvetenskapliga ämnen, där om-kunskaper fokuseras snarare än att lära genom att praktiskt arbeta med olika slags media. Teknikundervisning däremot görs främst $\mathrm{i}$ naturvetenskapliga ämnen där fokus är att lära sig använda hård- och mjukvara. Sefton-Green et al. påpekar att denna tudelning även påverkat förståelsen av digitalisering i både policydokument och i undervisningen.

Fenomenet multimodalitet tenderar även att förtingligas då en specifik modalitet sätts i fokus, vilket ofta varit fallet i tidigare studier av multimodalitet. En konsekvens av ett förtingligat förhållningssätt är att det multimodala i sig inte hamnar i fokus då det reduceras till en aspekt av något annat. En annan konsekvens är att specifika delar sätts i fokus snarare än det multi-modala vilket kan begränsa, eller till och med förhindra, en holistisk förståelse av multimodalitetens meningsskapande kvaliteter. Studier av hur flera modaliteter samspelar för att skapa mening är få (Bezemer \& Kress, 20I0; Christensen, 2016). Här finns alltså ett behov av forskning avseende hur modaliteter samverkar för att skapa mening inklusive kvalitativa aspekter av denna samverkan.

\section{Multimodalitet som stöd för annat lärande}

Den andra tematiska grupperingen visar på en uppfattning om multimodalitet som stöd för annat lärande: som underordnat annat lärande, som förberedelse för ett verbalspråkligt meningsskapande och som jämförelseobjekt:

\section{JÄMFÖRELSE}

\section{FÖRBEREDELSE}
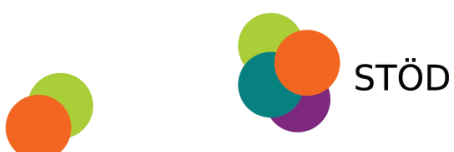

Figur 4. Multimodalitet som stöd för annat lärande 
Denna uppfattning finns på alla lärosäten och oftast i relation till flera av konstellationens aspekter. Multimodala medieformer används som jämförelseobjekt i analyser av skönlitteratur och andra litterära genrer, och vi tolkar skrivningarna som att det multimodala huvudsakligen agerar bakgrund till det verbalspråkliga. Multimodala skrivningars förekomst i främst kursplaner för F-3 indikerar att multimodalitet ses som mer relevant för yngre barn och som förberedelse för ett verbalspråkligt meningsskapande. I kursplanerna skrivs multimodalitet, estetiska lärprocesser, drama, digitala kommunikationsformer och media fram som stöd för huvudsakligen verbalspråklig utveckling men även för kommunikation, identitetsskapande och kreativitet. Estetiska ämnens möjligheter att bidra till lärandet har lyfts av flera forskare (se Lilliedahl, 20I8, för översikt) men estetiska ämnenas relation till andra ämnen har också problematiserats (t.ex. Dahlbäck \& Lyngfeldt, 2018; Eisner, 2004; Hetland et al., 2013; Lindgren, 2006; Lindgren \& Ericsson, 20I3). Problematiken relateras till verbalspråkets hegemoni och en syn på estetiska ämnen som hjälpämnen för kärnämnena; en syn som bekräftas även i vårt resultat.

Att utveckling av verbalspråket skrivs fram som överordnat i kursplaner för svenska är inte konstigt. Men resultatet synliggör även en verbalspråklig hegemoni inom svenskämnet, vilket överensstämmer med Dahlbäck och Lyngfeldts (2018) studie. Samtidigt som multimodalitet finns med som en del av kurserna så görs en tydlig skillnad mellan verbalspråklighet och andra sätt att uttrycka sig. Det verbalspråkliga i form av böcker med skriven text ges generellt ett större utrymme och när multimodalitet finns med tas ändå det verbalspråkliga som utgångspunkt, till exempel när skrivna verk jämförs med filmatiseringar. Multimodalitet nämns men ges inte möjlighet att utmana verbalspråkets särställning inom språkundervisning. Att skriva in multimodalitet i kursplanerna men samtidigt ge det en underordnad roll innebär att begreppet och vad det står för ges en begränsad möjlighet att faktiskt påverka svenskämnet. Kursplaner skrivna utifrån ett icke-hierarkiskt multimodalt perspektiv där alla uttryckssätt ses som meningsbärande skulle tydligar ifrågasätta och utmana verbalspråkets särställning.

Multimodalitet som kunskapande $i$ sin egen rätt

Den tredje tematiska grupperingen avser ett förhållningssätt till multimodalitet som ett kunskapande i sin egen rätt: som en egen kunskapsform, som idé och som praktik:

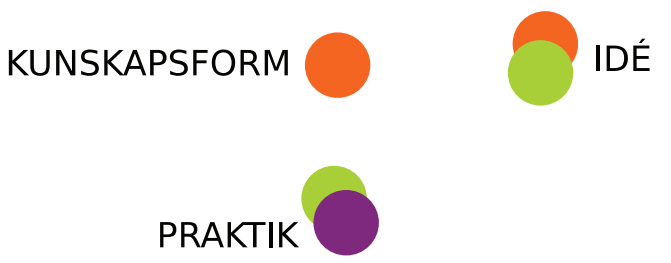

Figur 5. Multimodalitet som kunskapande i sin egen rätt

Tre av fyra lärosäten finns representerade här, men temat uttrycks ändå relativt sparsamt i materialet. Multimodala arbetsformer, uttrycksformer och synsätt skrivs här uttryckligen fram i sin egen rätt utan att reduceras till ett stöd för det verbalspråkliga. I kursplanerna förekommer två varianter av detta; dels som idé och om-kunskap och dels som praktiskt görande och tränande av specifikt multimodala färdigheter och kunskaper. Oavsett vilket, fokuseras en i 
fenomenografisk mening holistisk förståelse av multimodalitet i motsats till det atomistiska förhållningssätt som nämnts tidigare. Det multimodala delas inte upp i hanterbara delar utan lärandet avser själva multimodalitetens kvaliteter. Att förstå multimodalitet på detta vis innebär att se till relationerna mellan flera modaliteter, istället för varje enskild modalitet. Det innebär också en icke-hierarkisk syn på uttryckssätt där alla modaliteter tillsammans utgör en odelbar helhet. Att utgå från en relationell transformativ kunskapssyn, som beskrivits tidigare med hänvisning till Barad (2007), Biesta (2004) och Marton \& Booth (1997), är ett sätt att fokusera multimodalitetens holistiska kvaliteter i undervisnings- och forskningssammanhang. Begreppet performativitet blir också relevant här, vilket diskuteras mer ingående i följande avsnitt.

\section{DISKUSSION}

I denna studie har kursplaner i svenskämnet på grundlärarprogrammet vid fyra olika lärosäten i Sverige analyserats i syfte att belysa skillnader i förhållningssätt till, och därmed förutsättningar för, meningsskapande i multimodala praktiker. Med en fenomenografisk ansats urskiljdes elva uppfattningar av multimodalitet så som de uttryckts i kursplaneskrivningarna. På metanivå framträder en spänning mellan vad vi uppfattar som två synsätt på multimodalitet, ett med fokus på representation och ett med fokus på performativitet. För att synliggöra spänningen mellan de två synsätten, samt de förutsättningar för multimodalt meningsskapande som de ger upphov till, använder vi oss av begreppen diskursiva praktiker och performativitet utifrån Butler (1993) och Barad (1998, 2007). Som tidigare nämnts tar Butler och Barad delvis olika utgångspunkter när de skriver om diskursiva praktiker. Barads främsta intresse är hur diskurser materialiseras medan Butler fokuserar på diskursers funktion och hur verbalspråket konstruerar individer.

Utifrån detta resonemang skulle de två första temana, det digitala och det stödjande, kunna relateras till en diskursiv praktik "á la Butler" eftersom verbalspråket huvudsakligen utgör utgångspunkten för den förståelse av multimodalitet som uttrycks. Det tredje temat däremot indikerar en syn på multimodalitet som en diskursiv praktik "á la Barad" eftersom den vilar på en icke-hierarkisk syn på språk som multimodalt. Liknande spänningar mellan de tematiska grupperingarna kan ses i relation till begreppet performativitet. Enligt en relationell kunskapssyn, handlar performativitet om görande och engagerande och denna syn uttrycks i den tredje tematiska grupperingen. Denna gruppering utmärks av ett fokus på process, snarare än produkt och även av en holistisk syn på multimodalitet. I de två andra grupperingarna handlar performativitet snarare om skapandet av en produkt, en representation, som kan bli föremål för bedömning. Karakteristiskt här är ett förtingligande av multimodalitet, exempelvis när en specifik modalitet fokuseras snarare än samspelet i det multimodala.

Skillnader i definitionen av performativitet knyter an till olikheter i begreppet diskursiva praktiker. Utifrån diskursiva praktiker "á la Butler" relateras performativitet till skapandet av en produkt i form av en multimodal representation som kan bedömas och där färdigheten $\mathrm{i}$ att göra denna kan tränas. Denna definition av performativitet är synlig i de flesta kursplaner och vi menar att även Elf et al. (20I8) tar performativitet "á la Butler" som utgångspunkt i sin beskrivning av förändringar i nordiska läroplaner avseende multimodalitet. De pekar på att fokus håller på att flyttas från elevers receptiva förmåga, dvs. förmåga att analysera multimodala representationer, mot det Elf et al. benämner som performativitet, dvs. elevers förmåga att själva producera multimodala representationer. I den tredje tematiska grupperingen definieras istället performativitet utifrån en relationell kunskapssyn. När performativitet ses som görande 
och engagerande är det själva processen i att skapa multimodala texter som är central och inte prestation och produkt.

\section{Pedagogiska implikationer}

Vi menar att skillnader i definition av performativitet kan vara en av anledningarna till svårigheterna i att bedöma multimodala texter i undervisningssammanhang. Bedömning fokuserar ofta på elevers representationer och kvaliteter i dessa. Denna performativitet, som ligger i linje med t.ex. Ball (2000), är lärare vana att bedöma. Dock är kunskapskraven i grund- och gymnasieskolans läroplaner formulerade utifrån elevprofiler som ska beskriva hur elever kan använda sin kunskap (t.ex. Sadler, 1987) vilket ligger mer i linje med en relationell och socio-materiell förståelse av performativitet (Barad, 2007). För att förstå och kunna värdera det arbete som görs behöver processen tas som utgångspunkt, t.ex. genom att fokusera på elevers val av modaliteter och deras resonemang kring hur dessa samspelar med varandra för att skapa mening.

Vilken multimodal kompetens behöver blivande lärare i svenska inom grundskolan för att kunna vägleda och utveckla sina elevers förmåga att uttrycka sig och utveckla kunskap i dagens mediala värld? Det är naturligtvis en fråga som är svår att svara på eftersom samhällsutvecklingen idag går fort och det är svårt att förutse vilka kunskaper som behövs för en samhällsmedborgare i mitten av 2000-talet. Dock är det högst sannolikt att vi även fortsättningsvis kommer att kommunicera via diverse olika digitala kanaler och att kommunikationen där kommer att ske både med bild, ljud och text. För att kunna stötta elevers utveckling till aktiva medborgare är det därför av vikt att blivande lärare utvecklar en förståelse för multimodalitet och hur det kan vara en del av deras undervisning. Vår analys av kursplaner visar att lärarstudenter främst möter multimodalitet i form av om-kunskap och i liten utsträckning får möjlighet att praktiskt erfara hur de med sina elever kan arbeta med multimodalitet i olika former. Vi menar också att även om kursplanerna tar upp multimodala aspekter av svenskämnet så utmanas inte verbalspråkets hegemoniska särställning. Istället ses det multimodala oftast som ett hjälpmedel för att utveckla verbalspråket.

Vår konklusion är att en relationell kunskapssyn skapar förutsättningar för att studera multimodalitetens holistiska kvaliteter, snarare än de enskilda modaliteternas karaktär. Genom att använda socio-materiell teori kan performativa och materiella kvaliteter synliggöras, vilket kan bidra till en mer holistisk förståelse av multimodalitet hos blivande lärare i svenska i grundskolan. Socialkonstruktivistiska teorier tenderar snarare att osynliggöra det performativa genom att fokusera på det diskursiva, och på så vis även upprätthålla verbalspråkets hegemoni. Multimodal teoribildning i sin tur tenderar att fokusera på delar och därmed förlora kvalitativa, holistiska aspekter av multimodalt meningsskapande. Som nämndes i inledningen är denna studie tänkt att ligga till grund för vidare studier av multimodalitet i lärarprogrammen. Kursplaner är enbart en del av undervisningens socio-materiella assemblage. Vi är medvetna om begränsningarna med detta fokus. Genom att i ett första steg avgränsa studien till en aktör synliggörs dock komplexiteten i multimodalitet samt behovet av att i fortsatta studier anlägga ett perspektiv som kan möta denna komplexitet.

\section{FÖRFATTARPRESENTATION}

Anna-Lena Godhe är docent i utbildningsvetenskap vid Malmö universitet. Hon är ämneslärare i grunden och doktorerade i tillämpad IT på Göteborgs universitet 20I4. Skapande och bedömning av multimodala texter var ett centralt tema i avhandlingen. Hennes forskningsintresse fokuserar på användningen av digitala verktyg i undervisning generellt och i språkundervisning specifikt. 
Ann-Mari Edström är lektor i bild och lärande vid Malmö universitet. Hon har en bakgrund som glaskonstnär och doktorerade i pedagogik vid Lunds universitet 2008 med avhandlingen Learning in Visual Art Practice. Hennes forskningsintressen inkluderar konstnärliga arbets- och lärandeprocesser, multimodalitet, gestaltande metod och metodologi.

\section{REFERENSER}

Aldrin, V. (2013). Kursguidernas roll i högre utbildning - en studie av kursguidebruk vid Göteborgs universitet. Högre utbildning, 3(1), 37-51. https://hogreutbildning.se/index.php/hu/article/view/825

Ball, S. (2000). Performativities and fabrications in the education economy: Toward the performative society. Australian Educational Researcher, 17(3), 1-24. https://doi.org/10.1007/bf03219719

Barad, K. (1998). Getting real: Technoscientific practices and the materialization of reality. Differences: A Journal of Feminist Cultural Studies, 10(2), 87-126.

Barad, K. M. (2007). Meeting the universe halfway: Quantum physics and the entanglement of matter and meaning. Duke University Press.

Bezemer, J. \& Kress, G. (2016). Multimodality, learning and communication - a social semiotic frame. Routledge. https://doi.org/10.4324/9781315687537

Biesta, G. (2004). "Mind the gap!" Communication and educational relation. I C. W. Bingham \& A. M. Sidorkin (Red.), No education without relation (s. 11-22). P. Lang.

Borgfeldt, E. (2017). "Det kan vara svårt att förklara på rader": Perspektiv på analys och bedömning av multimodal textproduktion i årskurs 3 [Doktorsavhandling, Göteborgs universitet]. GUPEA. http:// hdl.handle.net/2077/53675

Bruce, C. S. (1994). Research students' early experiences of the dissertation literature review. Studies in Higher Education, 19(2), 217-229. https://doi.org/10.1080/03075079412331382057

Butler, J. (1993). Bodies that matter: On the discursive limits of "sex". Routledge. https://doi.org/10.4324/ 9780203760079

Cederlund, C. \& Sofkova Hashemi, S. (2018). Multimodala bedömningspraktiker och lärares lärande. Educare, (1), 43-68. https://doi.org/10.24834/educare.2018.1.3

Christensen, V. (2016). Elevers produktion af multimodale tekster. Hvad ved vi og hvad mangler vi? Acta Didactica Norge, 10(3), Art 8. https://doi.org/10.5617/adno.2841

Dahlbäck, K. \& Lyngfelt, A. (2017). Estetiska dimensioner i svenskämnets kursplaner från Lgr 69 till Lgr 11. Educare, (1), 152-182. https://doi.org/10.24834/educare.2017.1.8

Eisner, E. W. (2004). What can education learn from the arts about the practice of education? International Journal of Education o the Arts, 5(4). http://www.ijea.org/v5n4/v5n4.pdf

Edström, A.-M. \& Wangen, B. (2020). Being in motion through an aesthetic working process. Educare, (1), 144-161. https://doi.org/10.24834/educare.2020.1.7

Elf, N., Gilje, Ø., Olin-Scheller, C. \& Slotte, A. (2018). Nordisk status og forskningsperspektiver: Multimodalitet i styredokumenter og klasserumsrumspraksis. I M. Rogne \& L. Rune Waage (Red.), Multimodalitet i skole- og fritidstekstar. Ein vitskapleg antologi (s. 71-104). Fagbokforlaget.

Godhe, A.-L. (2014). Creating and assessing multimodal texts - negotiations at the boundary. [Doktorsavhandling, Göteborgs universitet]. GUPEA. http://hdl.handle.net/2077/35488

Goodwin, C. (2000). Action and embodiment within situated human interaction. Journal of Pragmatics, 32, 1489-1522. https://doi.org/10.1016/S0378-2166(99)00096-X

Herbert, S. \& Pierce, R. (2013). Gesture as data for a phenomenographic analysis of mathematical conceptions. International Journal of Educational Research, 60(1), 1-10. https://doi.org/10.1016/j.ijer. 2013.03.004

Hetland, L., Winner, E., Veenema, S. \& Sheridan, K. M. (2013). Studio thinking 2 the real benefits of visual arts education. Teachers College Press.

Jonasson, C. (2020). "Jag har också rätt att ljudsätta världen": Om tjejers och transpersoners tillblivelser som musikskapare i musikteknologiska lärmiljöer [Doktorsavhandling, Lunds universitet]. https://lucris. lub.lu.se/ws/portalfiles/portal/78361845/Jag_har_ocks_r_tt_att_ljuds_tta_v_rlden.pdf 
Jones, C. (2018). Experience and networked learning. I N. B. Dohn, S. Cranmer, J.-A. Sime, M. de Laat \& T. Ryberg (Red.), Networked learning: Reflections and challenges (s. 39-55). Springer. https://doi. org/10.1007/978-3-319-74857-3

Kang, R., Mehranian, Y. \& Hyatt, C. (2017). Incorporating an image-based, multimodal pedagogy into global citizenship education. International Journal of Education \& the Arts, 18(23). http://www.ijea. org/v18n23/v18n23.pdf

Kress, G. (2010). Multimodality: A social semiotic approach to comtemporary communication. Routledge. https://doi.org/10.4324/9780203970034

Körkkö, M., Morales Rios, S. \& Kyrö-Ämmälä, O. (2019). Using a video as as a tool for reflective practice. Educational Research, 61(1), 22-37. https://doi.org/10.1080/00131881.2018.1562954

Latour, B. (2015). Tinget àterställt. En introduktion till actor-network theory. Studentlitteratur.

Law, J. (2004). After method. Routledge. https://doi.org/10.4324/9780203481141

Lilliedahl, J. (2018). Building knowledge through arts integration. Pedagogies: An International Journal, 13(2), 133-145. https://doi.org/10.1080/1554480x.2018.1454320

Lindgren, M. (2006). Att skapa ordning för det estetiska i skolan. Diskursiva positioner i samtal med lärare och skolledare [Doktorsavhandling, Göteborgs universitet]. GUPEA. http://hdl.handle.net/2077/16773

Lindgren, M. \& Ericsson, C. (2013). Diskursiva legitimeringar av estetisk verksamhet i lärarutbildningen. Educare - Vetenskapliga skrifter, (1), 7-40.

MacMillan, M. (2014). Student connections with academic texts: A phenomenographic study of reading. Teaching in Higher Education, 19(8), 943-954. https://doi.org/10.1080/13562517.2014.934345

Marton, F. \& Booth, S. (1997). Learning and awareness. Erlbaum. https://doi.org/10.4324/9780203053690

Maybee, C., Bruce, C. S., Lupton, M. \& Rebmann, K. (2017). Designing rich information experiences to shape learning outcomes. Studies in Higher Education, 42(12), 2373-2388. https://doi.org/ 10.1080/03075079.2016.1148684

Molin, L. \& Godhe, A.-L. (2020). Students' critical analyses of prominent perspectives in a digital multimodal text. Nordic Journal of Digital Literacy, 15(3), 153-164. https://doi.org/10.18261/issn.1891943x-2020-03-02

Olin-Scheller, C. (2006). Mellan Dante och Big Brother: En studie om gymnasieelevers textvärldar (Karlstad University studies, 2000:67). Karlstad university.

Sadler, R. (1987). Specifying and promulgating achievement standards. Oxford Review of Education, 13(2), 191-209. https://doi.org/10.1080/0305498870130207

Sefton-Green, J., Nixon, H. \& Erstad, O. (2009). Reviewing approaches and perspectives on "digital literacy". Pedagogies: An International Journal, 4(2), 107-125. https://doi.org/10.1080/15544800 902741556

Silseth, K. \& Gilje, Ø. (2017). Multimodal composition and assessment: A sociocultural perspective. Assessment in Education: Principles, Policy \& Practice, 26(1), 26-42 https://doi.org/10.1080/09695 94X.2017.1297292

Speed, C. L. (2008). Sustainable dwelling: A phenomenography of house, home and place [Doktorsavhandling]. RMIT University, Melbourne.

Svensson, L. (1976). Study skill and learning [Doktorsavhandling]. Göteborgs universitet.

Svensson, L. (1997). Theoretical foundations of phenomenography. Higher Education Research \& Development, 16(2), 159-171. https://doi.org/10.1080/0729436970160204

Tønnessen, E. S. (2011). Multimodal textkompetense og dataspill. Svenskämnet i förändring? Perspektiv på de nya kurs- och ämnesplanerna. Svensklärarföreningen, 7, 82-99.

Aagaard, T. \& Silseth, K. (2017). Teachers' assessment of digital stories: Challenges and dilemmas. Nordic Studies in Education, 27(3-4), 231-242. https://doi.org/10.18261/issn.1891-5949-2017-03-04-08 